Article

\title{
Human Ovarian Granulosa Cells Isolated during an IVF Procedure Exhibit Differential Expression of Genes Regulating Cell Division and Mitotic Spindle Formation
}

\author{
Maciej Brązert ${ }^{1}$, Wiesława Kranc ${ }^{2}$, Błażej Chermuła ${ }^{1}$, Katarzyna Kowalska ${ }^{3}$, \\ Maurycy Jankowski ${ }^{2}{ }^{\mathbb{D}}$, Piotr Celichowski ${ }^{3}$, Michal Jeseta ${ }^{4}{ }^{\circ}$, Hanna Piotrowska-Kempisty ${ }^{5}$, \\ Leszek Pawelczyk ${ }^{1}$, Maciej Zabel ${ }^{6,7}$, Paul Mozdziak ${ }^{8}$ (D) and Bartosz Kempisty ${ }^{2,3,4, *}$ \\ 1 Division of Infertility and Reproductive Endocrinology, Department of Gynecology, Obstetrics and \\ Gynecological Oncology, Poznan University of Medical Sciences, 33 Polna St., 60-535 Poznań, Poland; \\ maciejbrazert@ump.edu.pl (M.B.); blazej.chermula@wp.pl (B.C.); pawelczyk.leszek@ump.edu.pl (L.P.) \\ Department of Anatomy, Poznan University of Medical Sciences, 6 Święcickiego St., 60-781 Poznań, Poland; \\ wkranc@ump.edu.pl (W.K.); mjankowski@ump.edu.pl (M.J.) \\ 3 Department of Histology and Embryology, Poznan University of Medical Sciences, 6 Święcickiego St., \\ 60-781 Poznań, Poland; kkowalsk@ump.edu.pl (K.K.); p.celichowski@gmail.com (P.C.) \\ 4 Department of Obstetrics and Gynecology, University Hospital and Masaryk University, 20 Jihlavská St., \\ 62500 Brno, Czech Republic; jeseta@gmail.com \\ 5 Department of Toxicology, Poznan University of Medical Sciences, 30 Dojazd St., 60-631 Poznań, Poland; \\ hpiotrow@ump.edu.pl \\ 6 Department of Histology and Embryology, Wroclaw Medical University, Chałubińskiego St., \\ 50-368 Wrocław, Poland; m.zabel@wlnz.uz.zgora.pl \\ 7 Division of Anatomy and Histology, University of Zielona Gora, 28 Zyty St., 65-046 Zielona Góra, Poland \\ 8 Physiology Graduate Program, North Carolina State University, Campus Box 7608, \\ Raleigh, NC 27695-7608, USA; pemozdzi@ncsu.edu \\ * Correspondence: bkempisty@ump.edu.pl; Tel.: +48-618-546-567; Fax: +48-618-546-568
}

Received: 12 October 2019; Accepted: 15 November 2019; Published: 20 November 2019

\begin{abstract}
Granulosa cells (GCs) are a population of somatic cells whose role after ovulation is progesterone production. GCs were collected from patients undergoing controlled ovarian stimulation during an in vitro fertilization procedure, and they were maintained for 1,7,15, and 30 days of in vitro primary culture before collection for further gene expression analysis. A study of genes involved in the biological processes of interest was carried out using expression microarrays. To validate the obtained results, Reverse Transcription quantitative Polymerase Chain Reaction (RT-qPCR) was performed. The direction of changes in the expression of the selected genes was confirmed in most of the examples. Six ontological groups ("cell cycle arrest", "cell cycle process", "mitotic spindle organization", "mitotic spindle assembly checkpoint", "mitotic spindle assembly", and "mitotic spindle checkpoint") were analyzed in this study. The results of the microarrays obtained by us allowed us to identify two groups of genes whose expressions were the most upregulated (FAM64A, ANLN, TOP2A, CTGF, CEP55, BIRC5, PRC1, DLGAP5, GAS6, and NDRG1) and the most downregulated (EREG, PID1, INHA, RHOU, CXCL8, SEPT6, EPGN, RDX, WNT5A, and EZH2) during the culture. The cellular ultrastructure showed the presence of structures characteristic of mitotic cell division: a centrosome surrounded by a pericentric matrix, a microtubule system, and a mitotic spindle connected to chromosomes. The main goal of the study was to identify the genes involved in mitotic division and to identify the cellular ultrastructure of GCs in a long-term in vitro culture. All of the genes in these groups were subjected to downstream analysis, and their function and relation to the ovarian environment are discussed. The obtained results suggest that long-term in vitro cultivation of GCs may lead to their differentiation toward another cell type, including cells with cancer-like characteristics.
\end{abstract}


Keywords: ovarian granulosa; human; in vitro; cell division

\section{Introduction}

In the last phase of preovulatory follicle growth, mature oocytes are accompanied by somatic cells known as granulosa cells (GCs), with facilitation of the final steps of estrogen synthesis being their main function. From an oocyte viewpoint, the most important function of GCs is their participation in bidirectional communication, which allows for the exchange of signals and cellular metabolites between these two cell types [1]. GCs are an important factor in the comprehension of the folliculogenesis process [2,3]. However, understanding their transcriptome may be an important step in expanding knowledge about their possible application to medicine of the 21st century. This includes the significant stem-like potential of in vitro cultured GCs (described by Kossowska-Tomaszczuk et al.), which could be employed in the fields of regenerative and reconstructive medicine [4-7]. In addition, an analysis of GC gene expression in long-term in vitro cultures could help to define new therapeutic goals in the rapidly expanding field of infertility treatment [8].

DNA expression microarrays have become a useful technique in gene expression analysis [9], providing the opportunity to learn about many genetic pathways involved in the processes associated with in vitro culture conditions [10]. Microarray technology has enabled the discovery of many ontological groups involved in molecular cell division processes [11,12]. An analysis of the GC transcriptome during long-term in vitro culture may be useful in expanding knowledge about the mechanisms involved in their proliferation and possible differentiation in conditions different from physiological ones [13].

Hence, the major aim of this study was to describe the expression of genes involved in several gene ontologies associated with the process of cellular division ("cell cycle arrest", "cell cycle process", "mitotic spindle organization", "mitotic spindle assembly checkpoint", "mitotic spindle assembly", and "mitotic spindle checkpoint") during a primary long-term in vitro culture. The resulting set of genes of interest were then related to current knowledge about their involvement in physiological and in vitro granulosa-associated processes. This allowed for a better understanding of the molecular drivers underlying the in vitro proliferation of human granulosa cells and determined new markers of that process that had not been previously associated with cell building in the follicle. The obtained data could serve as a basic molecular reference for further studies that aim to fully encompass the mechanisms of in vitro cultured granulosa, ultimately aiming to employ these cells in fields such as assisted reproduction or regenerative medicine. The study additionally employed transmission electron microscopy (TEM) to provide additional information about the cells present in the culture and in cell-cycle-associated processes.

\section{Materials and Methods}

\subsection{Patient Selection and Granulosa Cell Separation}

Patients subjected to in vitro fertilization (IVF) procedures were the source of GCs in our study. After giving consent, 20 patients with diagnosed infertility (aged 18-40) qualified for this study. Patients with a potential risk of inadequate ovarian stimulation-according to Bologna's criteria of poor ovarian responders, which was published by the European Society of Human Reproduction and Embryology (ESHRE) in 2011 [14] were excluded (using a serum antimullerian hormone (AMH) level of $0.7 \mathrm{ng} / \mathrm{mL}$ as a cut-off value). Moreover, patients with endometriosis, polycystic ovary syndrome (PCOS), fewer than 9 antral follicles, and/or day 2-3 follicle-stimulating hormone (FSH) serum levels higher than $15 \mathrm{mU} / \mathrm{mL}$ were excluded. Furthermore, each of the samples included in the study was collected from a patient who had had $2-5$ ovarian follicles punctured during the procedure to improve the reliability 
of the results. In vitro fertilization procedures were conducted in the Department of Infertility and Reproductive Endocrinology, Poznań Medical University, Poznań.

Patients with previously diagnosed infertility were subjected to the procedure of controlled ovarian hyperstimulation. For ovarian stimulation, FSH (Gonal-F, Merck Serono, Darmstadt, Germany) and highly purified human menopausal gonadotropin (hMG-HP, Menopur, Ferring, Saint-Prex, Switzerland) were used. To suppress pituitary function, injections of Cetrorelix Acetate (Cetrotide, Merck Serono, Darmstadt, Germany) were administered in an adequate dose. Ovulation was evoked by subcutaneous injection of $6500 \mathrm{U}$ of human chorionic gonadotropin (hCG; Ovitrelle, Merck-Serono, Darmstadt, Germany). After oocyte pick-up (OPU), cumulus-oocyte complex (COC) and the remaining follicular fluid (FF) from each ovary were collected for further analysis. FF with suspended GCs was collected only from ovarian follicles larger than $16 \mathrm{~mm}$. To separate and collect GCs, the FF samples were subjected to centrifugation for $10 \mathrm{~min}$ at $200 \times g$ to obtain a GC-containing pellet $[15,16]$. The Poznań University of Medical Sciences Bioethical Committee gave approval for the study under resolution 558/17. All patients meeting the assumed criteria of the study expressed their informed, written consent for participation in this research.

\subsection{Cell Culture}

The cells obtained from patients undergoing IVF fertilization procedures were washed twice in culture medium through centrifugation at $200 \times g$ for $10 \mathrm{~min}$ at room temperature (RT). The culture medium consisted of Dulbecco's Modified Eagle Medium (DMEM, Sigma; Merck KGaA, Darmstadt, Germany), 2\% fetal bovine serum (FBS, Sigma; Merck KGaA, Darmstadt, Germany), $10 \mathrm{mg} / \mathrm{mL}$ gentamicin (Invitrogen; Thermo Fisher Scientific, Inc., Waltham, MA, USA), 4 mM L-glutamine (stock $200 \mathrm{mM}$, Invitrogen; Thermo Fisher Scientific, Inc., Waltham, MA, USA), 10,000 $\mu \mathrm{g} / \mathrm{mL}$ streptomycin, and 10,000 U/mL penicillin (Invitrogen; Thermo Fisher Scientific, Inc., Waltham, MA, USA) $[15,17]$.

The GC culture was maintained in conditions of $37{ }^{\circ} \mathrm{C}$ and $5 \% \mathrm{CO}_{2}$. When it reached $90 \%$ confluency, the cells were separated from the vessel using $0.05 \%$ trypsin- EthylenoDiamineTetraAcetic (trypsine - EDTA Invitrogen; Thermo Fisher Scientific, Inc., Waltham, MA, USA) for 1-2 min and were subjected to counting with the use of an ADAM Cell Counter and Viability Analyzer (ADAM CCVA) (Bulldog Bio, Portsmouth, NH, USA) (Adam CCVA). The culture was carried out for 30 days. The medium was changed twice per week. Total RNA was isolated after 1, 7, 15, and 30 days of culture. The ADAM CCVA was used to test the viability of each collected sample, and samples containing $95 \%$ or more viable cells were used for subsequent molecular analyses. The samples from each patient were cultured separately, with the RNA material from specific culture periods pooled before the microarray and RT-qPCR analysis. Different time periods were obtained from different patient samples, with pooling serving to alleviate the patient-specific transcript variation.

\subsection{Transmission Electron Microscopy Analysis}

For the transmission electron microscopy analysis, a suspension containing a fraction of human ovarian granulosa cells harvested during the mentioned time intervals of in vitro primary culture was used. The cells were fixed in $2.5 \%$ glutaraldehyde (Polysciences, Inc., Hirschberg an der Bergstraße, Germany) and rinsed with phosphate buffer. Next, the samples were postfixed with $1 \%$ osmium tetroxide. After rinsing the samples in phosphate buffer, dehydration with increasing concentrations of ethanol (from $50 \%$ to $100 \%$ ) was performed at $4{ }^{\circ} \mathrm{C}$. In the next step, the cell pellets were placed in a mixture of ethanol with acetone, acetone, and then an acetone/resin mixture. Later, the samples were embedded in epoxy resin and sliced into thin and ultrathin slices using a Leica Ultracut UCT (Leica Microsystems, Nussloch, Germany). The slices were first stained with toluidine blue and then with uranyl acetate and lead citrate. An ultrastructural analysis of sections considered representative (cells not mechanically damaged) was performed using a JEM 1010 (Jeol, Tokyo, Japan). 


\subsection{RNA Isolation}

Total RNA was isolated from the GCs of 20 patients after 1, 7, 15, and 30 days of culture using the Chomczyński-Sacchi method [18]. The harvested cells were suspended in $1 \mathrm{ml}$ of phenol and guanidine thiocyanate monophase solution (TRI Reagent ${ }^{\circledR}$, Sigma-Aldrich, St. Luis, MO, USA). To obtain three separate phases, chloroform was added. The RNA was located in the uppermost aqueous phase. Then, the RNA was stripped with 2-propanol (Sigma; Merck KGaA St. Luis, MO, USA; catalog number I9516) and washed with 75\% ethanol. Samples of extracted RNA were used for further analysis. The total mRNA amount was determined from the optical density at $260 \mathrm{~nm}$, and the RNA purity was estimated using a 260/280-nm absorption ratio (NanoDrop spectrophotometer, Thermo Scientific, Poland). Samples with a 260/280 absorbance ratio greater than 1.8 were used in the study.

\subsection{Microarray Analysis}

The microarray analysis was conducted according to protocols used in previous studies by our team [16,19-21]: $100 \mathrm{ng}$ RNA from each pooled sample (2 samples from each time interval) was subjected to two rounds of sense cDNA amplification (Ambion ${ }^{\circledR}$ WT Expression Kit, Ambion, Austin, TX, USA). The resulting cDNA was biotin-labeled and further fragmented using an Affymetrix GeneChip ${ }^{\circledR}$ WT (Affymetrix, Santa Clara, CA, USA). The biotin-labeled $(5.5 \mu \mathrm{g})$ fragments were hybridized with an Affymetrix ${ }^{\circledR}$ U219 Human Genome Array (Affymetrix, Santa Clara, CA, USA) $\left(48^{\circ} \mathrm{C} / 20 \mathrm{~h}\right)$. Then, they were washed and stained with the use of an Affymetrix GeneAtlas Fluidics station. The array stripes were then subjected to scanning using the GeneAtlas system imaging station. Affymetrix GeneAtlas ${ }^{\mathrm{TM}}$ Operating Software (v. 2.0.0.460, Affymetrix, Santa Clara, CA, USA) was used for the reading analysis. Data quality was approved in accordance with the software quality control criteria. The obtained CEL files were subjected to further data analysis [22,23].

Bioconductor software (v. 3.1.0, www.bioconductor.org) and R 3.5.1 programming language (www.r-project.org) were used for the analysis and graph compilation. The CEL files were merged with the description file. The background was corrected with the use of robust multiarray averaging (RMA), which was also employed for results normalization and summarization. The differentially expressed genes were selected on the basis of an adjusted $p$-value lower than 0.05 and an expression greater than two-fold. A list of differentially expressed genes (separated for up- and downregulated genes) was uploaded to DAVID software (v.6.8, Database for Annotation, Visualization and Integrated Discovery; Leidos Biomedical Research, Inc., National Cancer Institute, Frederick, MD, USA) (a database for annotation, visualization, and integrated detection) [24].

To predict the interactions between individual genes, sets of genes belonging to the Gene Ontology Biological Processes (GO BPs) of interest were uploaded into the STRING software (v. 10, Search Tool for Retrieval of Interacting Genes/Proteins, STRING Consortium, Lausanne, Switzerland) [25]. The STRING database contains data on protein/gene interactions that have been obtained through experimentation, computational forecasting methods, and analyses of the available public literature.

In order to further investigate the selected sets of genes, we examined their mutual relations with the GOplot package [26].

\subsection{RT-qPCR Analysis}

To confirm the results obtained from the microarrays, RT-qPCR was performed: 10 upregulated genes and 10 downregulated genes were selected from the GOs of interest. Three biological samples of each gene were used for the analysis. Each analysis was carried out in three technical repetitions. Reverse transcription was performed using SABiosciences (RT2 First Stand Kit-330401) and a 96-well Veritimer thermocycler. For the reverse transcription, $1 \mathrm{mg}$ of RNA transcript was used [17].

Real-time PCR was performed using a Light $\mathrm{Cycler}^{\circledR} 96$ (Roche Diagnostic GmbH, Manheim, Germany), RT2 SYBR ${ }^{\circledR}$ Green ROX ${ }^{\mathrm{TM}}$ qPCR Master Mix (Qiagen Sciences, Gaithersburg, MD, USA), and sequence-specific primers (Table 1). 
Table 1. Oligonucleotide sequences of primers used for RT-qPCR analysis: the primers of the 10 most upregulated and 10 most downregulated genes.

\begin{tabular}{|c|c|c|}
\hline Gene Name & Primer Sequence $\left(5^{\prime}-3^{\prime}\right)$ & Product Size (bp) \\
\hline NDRG1 & $\begin{array}{l}\text { F: ACAACCCTGAGATGGTGGAG } \\
\text { R: TGTGGACCACTTCCACGTTA }\end{array}$ & 174 \\
\hline GAS6 & $\begin{array}{l}\text { F: ATCAAGGTCAACAGGGATGC } \\
\text { R: CTTCTCCGTTCAGCCAGTTC }\end{array}$ & 187 \\
\hline DLGAP5 & $\begin{array}{l}\text { F: CCAGTCGACACAGGAAGGAT } \\
\text { R: CATTGCCCTTGGCTTAACAT }\end{array}$ & 227 \\
\hline PRC1 & $\begin{array}{l}\text { F: TAGACCACACCCCAGACACA } \\
\text { R: GTGGCCACAGCTTCTCTTTC }\end{array}$ & 223 \\
\hline BIRC5 & $\begin{array}{l}\text { F: GCCTTTCCTTAAAGGCCATC } \\
\text { R: AACCCTTCCCAGACTCCACT }\end{array}$ & 187 \\
\hline CEP55 & $\begin{array}{l}\text { F: CAGTATCCAGCCACTGAGCA } \\
\text { R: GGGAGGTATCACTGCCAAGA }\end{array}$ & 245 \\
\hline CTGF & $\begin{array}{l}\text { F: GGAAAAGATTCCCACCCAAT } \\
\text { R: TGCTCCTAAAGCCACACCTT }\end{array}$ & 153 \\
\hline TOP2A & $\begin{array}{l}\text { F: AATCTCAGAGCTTCCCGTCA } \\
\text { R: TGCCTCTGCCAGTTTTTCTT }\end{array}$ & 175 \\
\hline$A N L N$ & $\begin{array}{l}\text { F: ATGCAGTGTGGTGCACATTT } \\
\text { R: AACCCAAACACTTTGGCAAG }\end{array}$ & 195 \\
\hline FAM64A & $\begin{array}{l}\text { F: GGAGATCTCTCCAGCACCAG } \\
\text { R: GCACCCAAAGCACTCTTAGC }\end{array}$ & 244 \\
\hline$E Z H 2$ & $\begin{array}{l}\text { F: AGGACGGCTCCTCTAACCAT } \\
\text { R: CTTGGTGTTGCACTGTGCTT }\end{array}$ & 179 \\
\hline WNT5A & $\begin{array}{l}\text { F: TGGCTTTGGCCATATTTTTC } \\
\text { R: CCGATGTACTGCATGTGGTC }\end{array}$ & 199 \\
\hline$R D X$ & $\begin{array}{l}\text { F: CCCAGAGACTCTTCTTCTTGC } \\
\text { R: TACACGCTGGGGTAGGAGTC }\end{array}$ & 179 \\
\hline$E P G N$ & $\begin{array}{l}\text { F: TGACAGCACTGACCGAAGAG } \\
\text { R: CTCATGGTGGAATGCACAAG }\end{array}$ & 188 \\
\hline SEPT6 & $\begin{array}{l}\text { F: TCTGCTTCAACATCCTGTGC } \\
\text { R: GCTTTAGCCTCACGTTGCTC }\end{array}$ & 168 \\
\hline CXCL8 & $\begin{array}{l}\text { F: AAGAAACCACCGGAAGGAAC } \\
\text { R: AAATTTGGGGTGGAAAGGTT }\end{array}$ & 183 \\
\hline RHOU & $\begin{array}{l}\text { F: AGGCCTCTCTGCTACACCAA } \\
\text { R: TCAGGCACTGGCTTTTCTTT }\end{array}$ & 215 \\
\hline INHA & $\begin{array}{l}\text { F: CCAGCTGTGAGGACAAGTCA } \\
\text { R: CTAGCAGGGGCTCAGAGCTA }\end{array}$ & 186 \\
\hline PID1 & $\begin{array}{l}\text { F: TACCTGGGCAAAGTCTCCAC } \\
\text { R: TTTGTGGTCGAGATGATGGA }\end{array}$ & 171 \\
\hline EREG & $\begin{array}{l}\text { F: CCAAGGACGGAAAATGCTTA } \\
\text { R: AAAATTAGCTGGGCATGGTG }\end{array}$ & 237 \\
\hline GAPDH & $\begin{array}{l}\text { F: TCAGCCGCATCTTCTTTTGC } \\
\text { R: ACGACCAAATCCGTTGACTC }\end{array}$ & 90 \\
\hline АСТВ & $\begin{array}{l}\text { F: AAAGACCTGTACGCCAACAC } \\
\text { R: CTCAGGAGGAGCAATGATCTTG }\end{array}$ & 132 \\
\hline HPRT1 & $\begin{array}{l}\text { F: TGGCGTCGTGATTAGTGATG } \\
\text { R: ACATCTCGAGCAAGACGTTC }\end{array}$ & 141 \\
\hline
\end{tabular}

For the controls, 3-phosphate glyceraldehyde dehydrogenase (GADPH), $\beta$-actin (ACTB), and hypoxanthine 1 (HPRT1) phosphoribosyl transferase were used. The gene expression was analyzed using relative quantification (RQ). The RT-qPCR primers were designed using Primer3Plus software 
(version 0.4.0; Whitehead Institute for Biomedical Research, Massachusetts Institute of Technology, Cambridge, MA, USA).

\subsection{Statistics}

Bioconductor software (v. 3.1.0, www.bioconductor.org) and R 3.5.1 programming language (www.r-project.org) served as tools to perform the statistical analyses. The empirical Bayes method was used to obtain the adjusted $p$-value of all the genes of interest, with Benjamini and Hochberg's false discovery rate used to correct the results for multiple comparisons $(p<0.05$ indicated a statistically significant difference). The same methods and selection criteria were used to estimate the statistical significance of the enriched GO terms and Kyoto Encyclopedia of Genes and Genomes (KEGG) pathways, with DAVID database software (v.6.8, Leidos Biomedical Research, Inc., National Laboratory for Cancer Research, Frederick, MD, USA; david.ncifcrf.gov) employed for these analyses. Each GO term and KEGG pathway was considered significantly enriched if it contained at least 5 differentially expressed genes, with $p<0.05$. An RT-qPCR statistical analysis was performed using the Real Statistics Resource Pack for MS Excel 2016, also using the abovementioned methods (Microsoft Corporation, Redmond, WA, USA) $[15,27,28]$.

\section{Results}

In this study, Affymetrix microarrays were used to determine the changes in expression of the GC transcriptome between the 1st, 7th, 15th, and 30th day of in vitro culture. An Affymetrix ${ }^{\circledR}$ Human $\mathrm{HgU} 219$ Array analysis yielded data about the expression of 22,480 transcripts. To be considered differentially expressed, the genes needed to exceed a fold change of $|2|$ and be characterized with a $p$-value below 0.05 . The inclusion criteria resulted in the qualification of 2278 different transcripts for the study. The complete set of genes detected in the microarray analysis was uploaded to the GEO database (https://www.ncbi.nlm.nih.gov/geo/query/acc.cgi?acc=GSE129919).

Here, 218 differentially expressed genes could be found in the GO BPs of interest. From that set, the genes of the 10 highest and 10 lowest mean changes in expression between 7, 15, and 30 days of culture were chosen for subsequent analyses.

Genes belonging to the "cell cycle arrest", "cell cycle process", "mitotic spindle assembly checkpoint", "mitotic spindle assembly", "mitotic spindle checkpoint", and "mitotic spindle organization" gene ontologies (gene ontology biological process terms (GO BPs)) were extracted with the use of DAVID software (Database for Annotation, Visualization, and Integrated Discovery). The DAVID analysis was applied separately to up- and downregulated gene sets, with an adjusted $p$-value below 0.05 serving as a criterion for selection. This allowed for the identification of $582 \mathrm{GOs}$ and 45 KEGG pathways that contained differentially expressed genes. A hierarchical clustering procedure was applied to the sets of genes of interest, which allowed for presenting the results in the form of heatmaps (Figure 1). Additionally, the exact fold expression changes of each of the analyzed genes are presented in Table 2.

Measurement of the enrichment levels of each of the GO BPs of interest was then used for further investigation of the changes in expression of the genes that they contained. These values were visualized as a circle in the form of $z$-scores (Figure 2).

At the same time, most of the genes did not exclusively belong to a singular GO. Because of that, the intersections between the GOs of interest were analyzed and are presented in a circle diagram (Figure 3).

In addition, STRING software was used to study the molecular interaction networks between the 20 selected genes. The detected networks included experimentally determined interactions, co-expression, and interactions determined through text-mining (Figure 4).

To quantitatively validate the results of the microarray analysis, the RT-qPCR method was employed. The results of the validation are presented as a bar graph (Figure 5). 
The analysis validated the course of expression in the majority of the 20 selected genes. Only one gene showed an opposite change in expression in one of the analyzed time periods (EPGN). The resulting variable result may have been caused by the fact that expression microarrays are a wide-scale method, while RT-qPCR was used to detect particular transcript variants with much larger quantitative precision. As fold changes are highly dependent on the values of individual sample expression levels, the difference in sensitivity of the methods can sometimes cause discrepancies [29]. In such cases, RT-qPCR results are usually treated as more representative, which was also the approach used in this study.

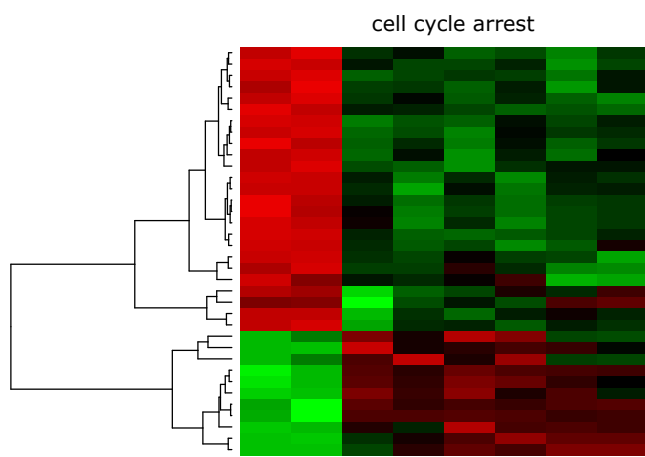

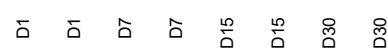

cell cycle process

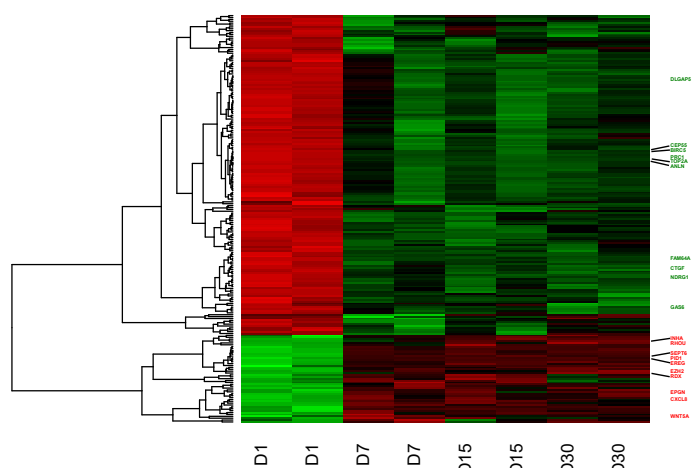

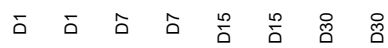

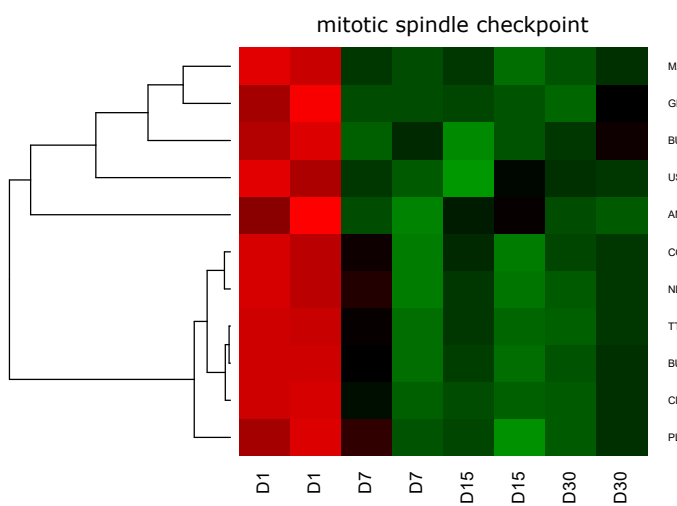

mitotic spindle organization

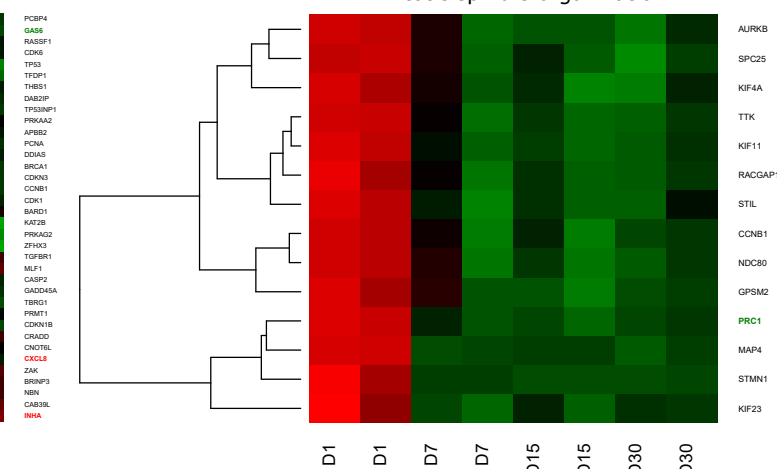

mitotic spindle assembly checkpoint

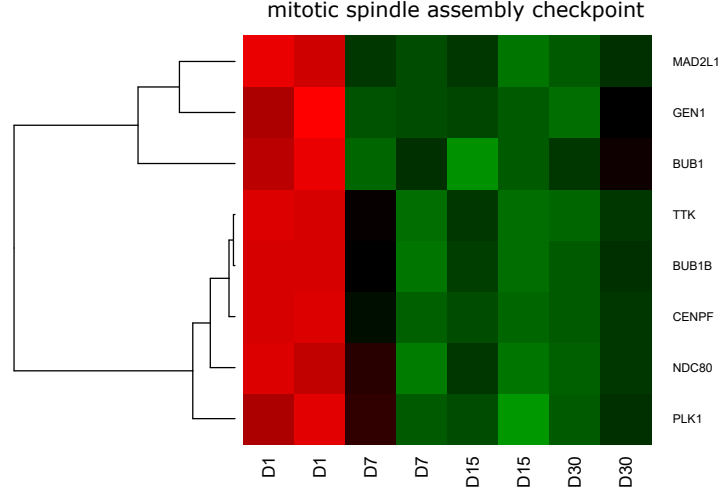

mitotic spindle assembly

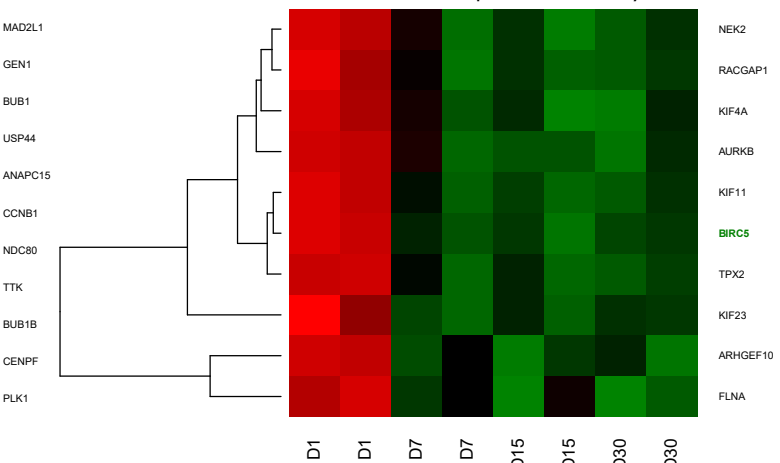

Figure 1. Heat map representation of differentially expressed genes belonging to the "cell cycle arrest", "cell cycle process", "mitotic spindle assembly checkpoint", "mitotic spindle assembly", "mitotic spindle checkpoint", and "mitotic spindle organization" gene ontology biological process (GO BP) terms. The arbitrary signal intensity acquired from the microarray analysis is represented by colors (green is higher expression and red is lower expression). $\log _{2}$ signal intensity values for any single gene were resized to a row $z$-score scale (from -2 , the lowest expression, to +2 , the highest expression for a single gene). 
Table 2. Gene symbols, fold changes in expression, Entrez gene IDs, and adjusted $p$-values of the studied genes. Red: downregulated genes; green: upregulated genes.

\begin{tabular}{|c|c|c|c|c|c|c|c|}
\hline Gene Symbol & $\begin{array}{c}\text { Fold Change } \\
\text { D7/D1 }\end{array}$ & $\begin{array}{c}\text { Fold Change } \\
\text { D15/D1 }\end{array}$ & $\begin{array}{l}\text { Fold Change } \\
\text { D30/D1 }\end{array}$ & $\begin{array}{c}\text { Adjusted } p \text {-Value } \\
\text { D7/D1 }\end{array}$ & $\begin{array}{c}\text { Adjusted } p \text {-Value } \\
\text { D15/D1 }\end{array}$ & $\begin{array}{c}\text { Adjusted } p \text {-Value } \\
\text { D30/D1 }\end{array}$ & Entrez Gene ID \\
\hline EREG & 0.010 & 0.008 & 0.008 & 0.0002 & 0.0002 & 0.0002 & 2069 \\
\hline PID1 & 0.076 & 0.068 & 0.071 & 0.0024 & 0.0020 & 0.0017 & 55022 \\
\hline INHA & 0.204 & 0.090 & 0.063 & 0.0266 & 0.0066 & 0.0036 & 3623 \\
\hline RHOU & 0.236 & 0.167 & 0.073 & 0.0481 & 0.0226 & 0.0061 & 58480 \\
\hline CXCL8 & 0.116 & 0.122 & 0.191 & 0.0189 & 0.0180 & 0.0337 & 3576 \\
\hline SEPT6 & 0.172 & 0.156 & 0.179 & 0.0006 & 0.0005 & 0.0005 & 23157 \\
\hline$E P G N$ & 0.169 & 0.220 & 0.149 & 0.0437 & 0.0621 & 0.0289 & 255324 \\
\hline$R D X$ & 0.306 & 0.273 & 0.129 & 0.0227 & 0.0153 & 0.0033 & 5962 \\
\hline WNT5A & 0.158 & 0.347 & 0.268 & 0.0184 & 0.0825 & 0.0407 & 7474 \\
\hline$E Z H 2$ & 0.259 & 0.369 & 0.185 & 0.0016 & 0.0031 & 0.0006 & 2146 \\
\hline NDRG1 & 11.930 & 22.621 & 20.319 & 0.0022 & 0.0011 & 0.0009 & 10397 \\
\hline GAS6 & 13.923 & 14.854 & 26.709 & 0.0059 & 0.0051 & 0.0024 & 2621 \\
\hline DLGAP5 & 14.126 & 22.518 & 20.818 & 0.0230 & 0.0124 & 0.0120 & 9787 \\
\hline PRC1 & 18.098 & 23.764 & 18.552 & 0.0016 & 0.0012 & 0.0012 & 9055 \\
\hline BIRC5 & 18.745 & 25.651 & 18.849 & 0.0029 & 0.0022 & 0.0023 & 332 \\
\hline CEP55 & 26.885 & 33.896 & 27.873 & 0.0056 & 0.0041 & 0.0042 & 55165 \\
\hline CTGF & 36.067 & 38.456 & 56.198 & 0.0028 & 0.0025 & 0.0015 & 1490 \\
\hline TOP2A & 45.408 & 58.461 & 50.754 & 0.0026 & 0.0020 & 0.0018 & 7153 \\
\hline ANLN & 59.052 & 63.936 & 59.669 & 0.0016 & 0.0013 & 0.0011 & 54443 \\
\hline FAM64A & 71.846 & 58.770 & 65.148 & 0.0009 & 0.0009 & 0.0007 & 54478 \\
\hline
\end{tabular}



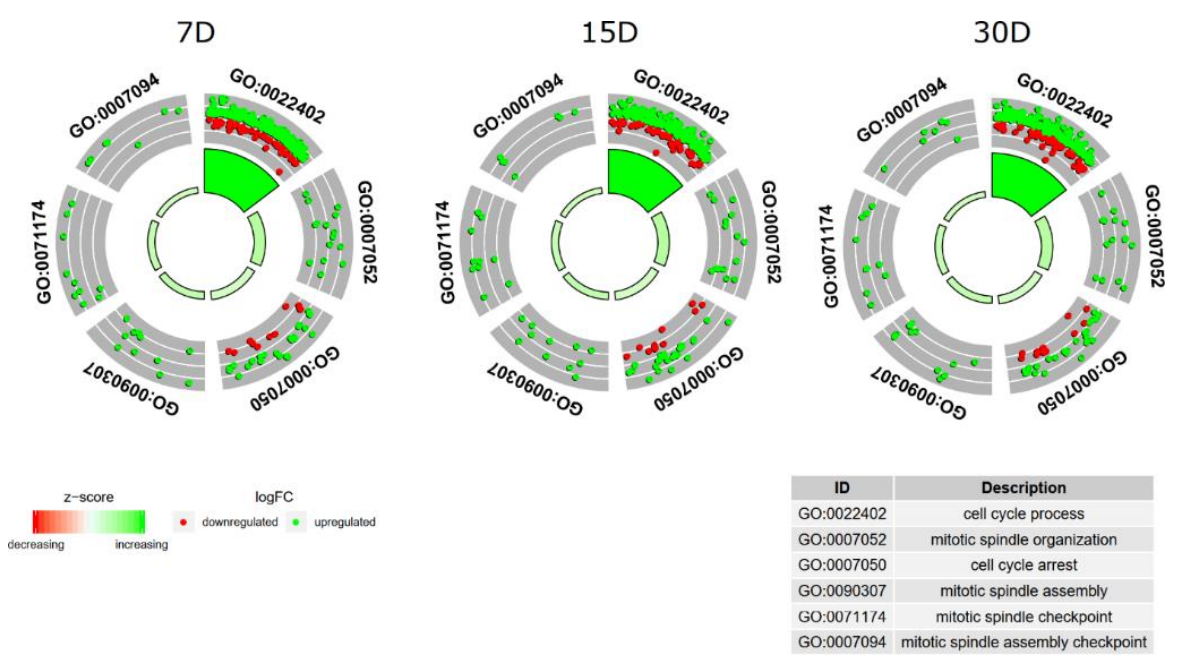

Figure 2. A circular visualization of the results of the gene annotation enrichment analysis. The outer circle shows a scatterplot for each term of the fold change logarithm (logFC) of the assigned genes. Green circles display upregulation, and red ones display downregulation. The inner circle is the representation of the $z$-score. The size and the color of the bar correspond to the value of the $z$-score. D-days of culture.

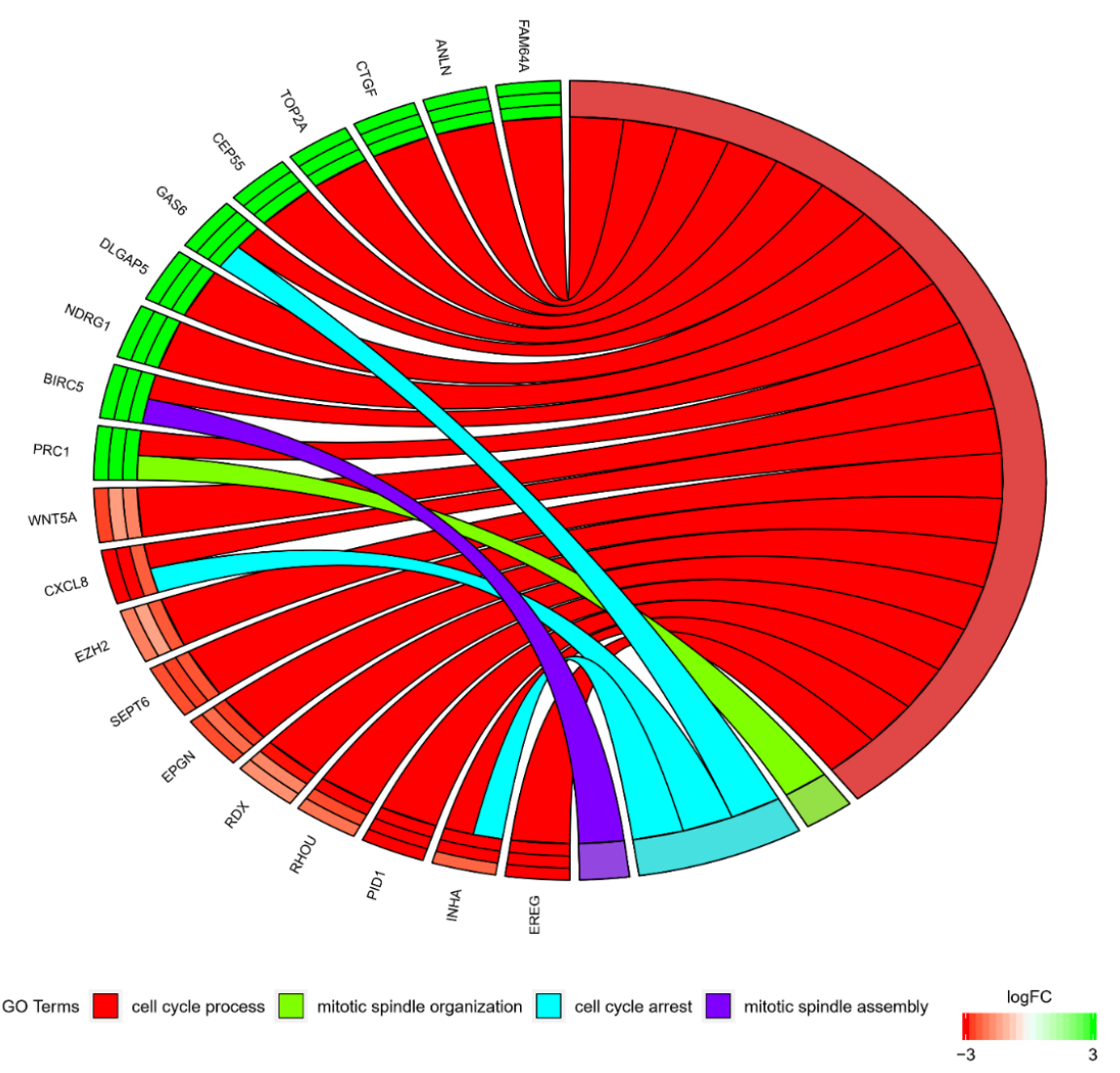

Figure 3. A representation of the mutual relationship between the 20 chosen genes that belonged to the "cell cycle arrest", "cell cycle process", "mitotic spindle assembly checkpoint", "mitotic spindle assembly", "mitotic spindle checkpoint", and "mitotic spindle organization" GO BP terms. The ribbons indicate which gene belongs to which category. The colors of the three inner bars near each gene correspond to the $\log \mathrm{FC}$ after 7,15 , and 30 days. The genes were sorted by $\operatorname{logFC}$. 


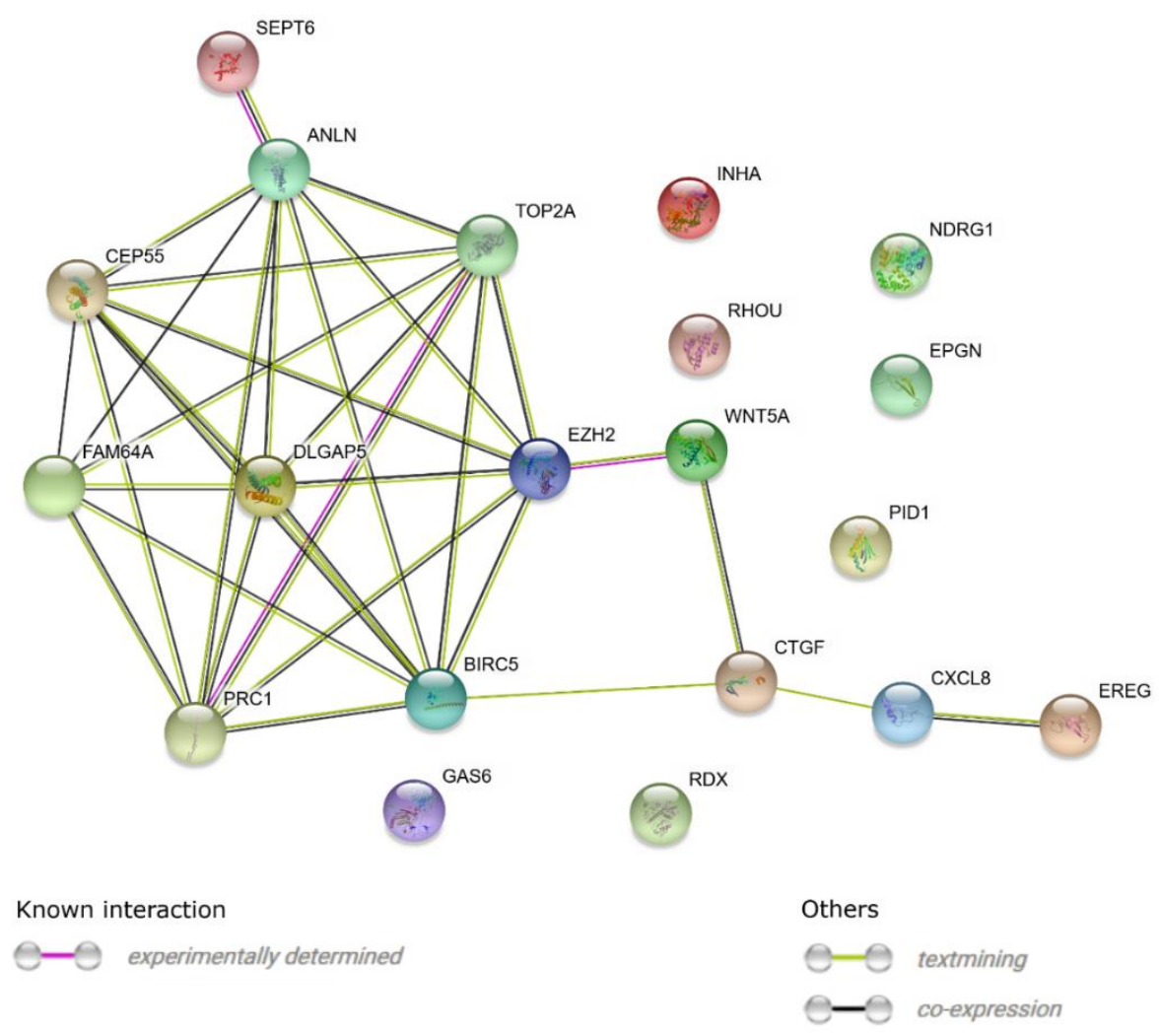

Figure 4. STRING-generated interaction network between the 20 chosen genes belonging to the "cell cycle arrest", "cell cycle process", "mitotic spindle assembly checkpoint", "mitotic spindle assembly", "mitotic spindle checkpoint", and "mitotic spindle organization" GO BP terms. The intensity of the edges reflects the strength of the interaction score.

To further investigate the potential phenotypical changes of the cells of interest, a morphological and ultrastructural evaluation was performed using light and transmission electron microscopy. The morphology of the GCs changed from a star-like cell shape into an elongated, fibroblast-like cell shape. Figure 6 shows the morphology of GCs at individual time intervals of the in vitro primary culture. During the analysis of cellular ultrastructure, the focus was placed primarily on structures related to mitotic cell division. The analysis showed the presence of a centrosome surrounded by a cloud of amorphous material forming a pericentric matrix with a radial microtubule system. Another characteristic structure for this process was mitotic spindles. The mitotic division of human GCs is illustrated in Figure 7. 


\begin{tabular}{|c|c|c|c|c|}
\hline NDRG1 & $\begin{array}{l}\square \text { RT-qPCR } \\
\square \text { MICROARRAY }\end{array}$ & $\begin{array}{l}7 \mathrm{7} \\
150 \\
30 \mathrm{D}\end{array}$ & 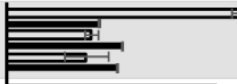 & \\
\hline FAM64A & & $\begin{array}{l}7 \mathrm{D} \\
15 \mathrm{D} \\
30 \mathrm{D}\end{array}$ & $\mid$ & \\
\hline ANLN & & $\begin{array}{r}7 \mathrm{D} \\
150 \mathrm{D} \\
30 \mathrm{D}\end{array}$ & 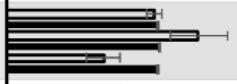 & \\
\hline TOP2A & & $\begin{array}{l}7 \mathrm{D} \\
15 \mathrm{D} \\
30 \mathrm{D}\end{array}$ & 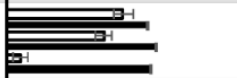 & \\
\hline CTGF & & $\begin{array}{l}7 \mathrm{D} \\
15 \mathrm{D} \\
30 \mathrm{D}\end{array}$ & 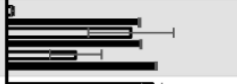 & \\
\hline CEP55 & & $\begin{array}{l}7 \mathrm{D} \\
150 \mathrm{D} \\
30 \mathrm{D}\end{array}$ & |l| & \\
\hline BIRC5 & & $\begin{array}{r}7 D \\
15 D \\
30 D\end{array}$ & 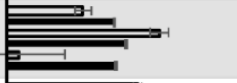 & \\
\hline PRC1 & & $\begin{aligned} 7 D \\
150 \\
30 D\end{aligned}$ & 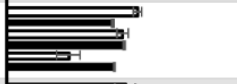 & \\
\hline DLGAP5 & & $\begin{aligned} 7 D \\
150 \\
30 D\end{aligned}$ & 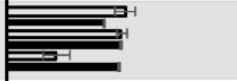 & \\
\hline GAS6 & & $\begin{array}{l}7 \mathrm{D} \\
15 \mathrm{D} \\
30 \mathrm{D}\end{array}$ & हो=1 & \\
\hline $\mathrm{EZH} 2$ & 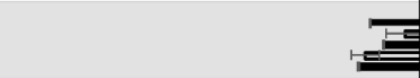 & $\begin{array}{l}7 \mathrm{D} \\
15 \mathrm{D} \\
30 \mathrm{D}\end{array}$ & & \\
\hline WNT5A & & $\begin{array}{l}75 \\
150 \\
30 D\end{array}$ & & \\
\hline RDX & & $\begin{array}{l}7 \mathrm{D} \\
15 \mathrm{D} \\
30 \mathrm{D}\end{array}$ & & \\
\hline EPGN & & $\begin{array}{l}70 \\
150 \\
300\end{array}$ & 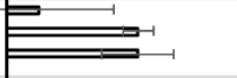 & \\
\hline SEPT6 & & $\begin{array}{l}7 \mathrm{D} \\
15 \mathrm{D} \\
30 \mathrm{D}\end{array}$ & & \\
\hline CXCL8 & & $\begin{array}{l}7 \mathrm{D} \\
15 \mathrm{D} \\
30 \mathrm{D}\end{array}$ & & \\
\hline RHOU & & $\begin{aligned} 7 \mathrm{D} \\
15 \mathrm{D} \\
30 \mathrm{D}\end{aligned}$ & & \\
\hline INHA & & $\begin{array}{l}7 \mathrm{D} \\
15 \mathrm{D} \\
30 \mathrm{D}\end{array}$ & $=$ & \\
\hline PID1 & 10 & $\begin{array}{l}7 D \\
150 \\
30 D\end{array}$ & & \\
\hline EREG & 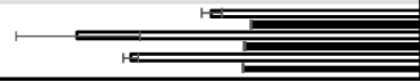 & $\begin{array}{r}70 \\
150 \\
300 \\
\end{array}$ & & LOG2(FC) \\
\hline
\end{tabular}

Figure 5. The results of the RT-qPCR validation of expression microarrays (log (FC)), presented as a bar graph. Error bars represent the standard error of the mean (SEM; $n=3)$. All of the presented sample means were deemed to be statistically significant $(p<0.05)$. D: day of culture; FC: fold change. 


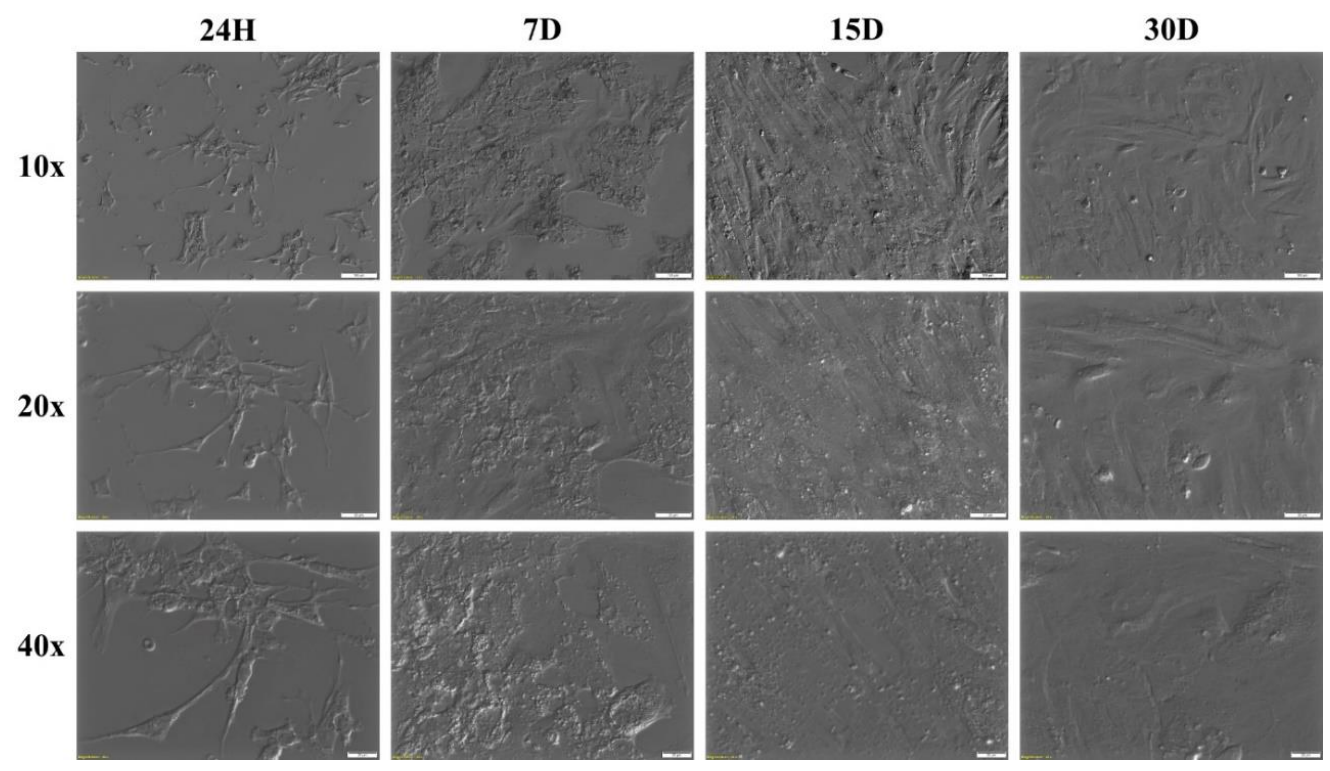

Figure 6. Change in granulosa cell (GC) morphology during long-term in vitro primary culture. $24 \mathrm{H}$ : first day of culture; D: day of culture; 10×, 20×, 40×: magnification.
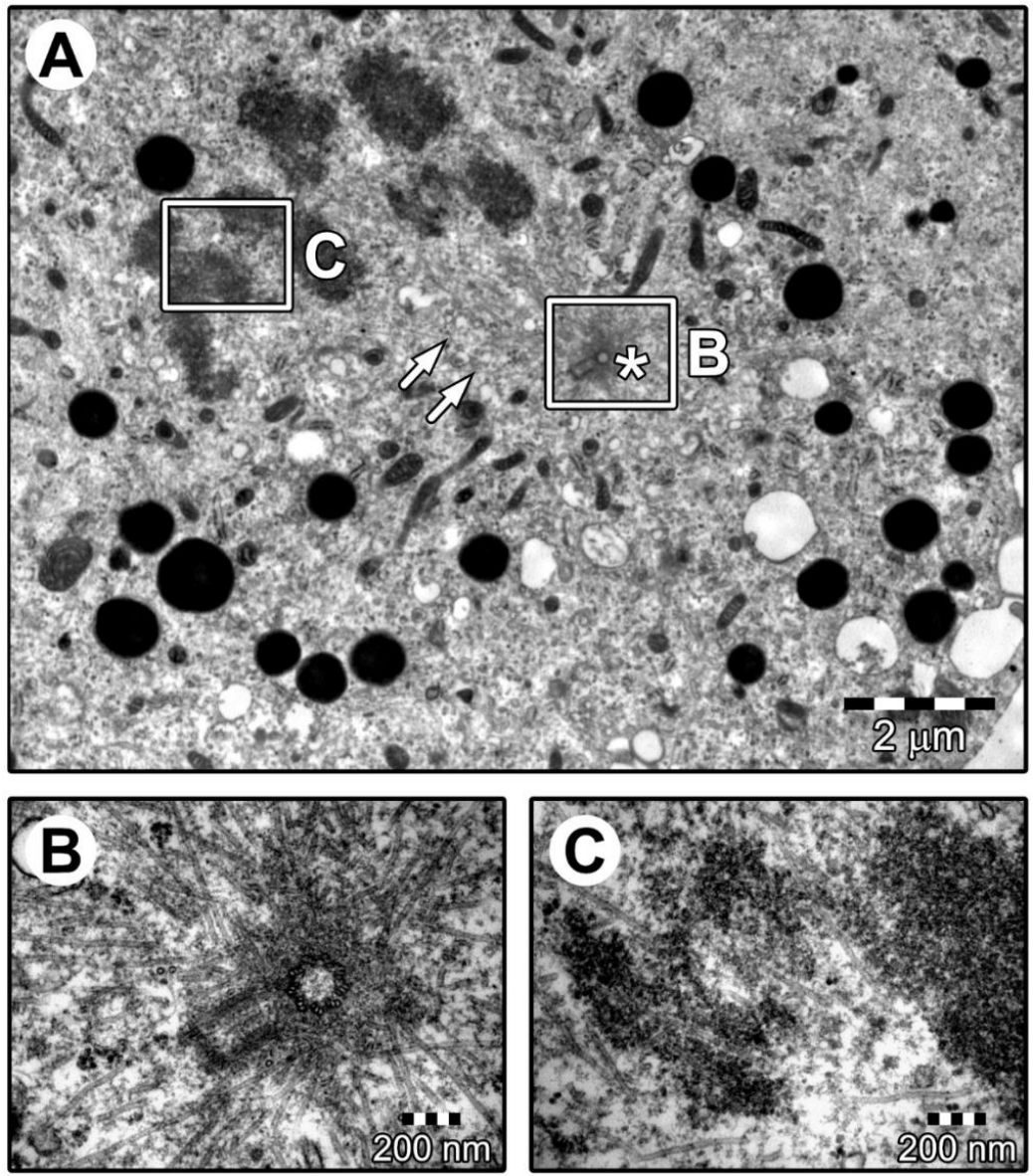

Figure 7. Human ovarian granulosa cells during mitotic division. Human ovarian GC cultures (day 7). Micro-electrophotography showing cells during mitotic division (A). The centrosome (star-like shape) is surrounded by a cloud of amorphous material forming a pericentric matrix, along with a radial microtubule system (B). Structures of the mitotic spindles (arrows) are visible, connecting to the chromosomes located in the equatorial plane (C). 


\section{Discussion}

In this study, an analysis of GC transcriptomes in individual time intervals was supplemented by an examination of their ultrastructure. The obtained results clearly indicate that these cells proliferated in long-term primary in vitro culture. This was indicated by the presence of centrosomes surrounded by the pericentric matrix, as well as the radial microtubule system. In addition, the mitotic spindle connected with chromosomes located in the equatorial plane. Earlier analyses using an electron transmission microscope focused primarily on structures related to the secretory properties of these cells $[30,31]$. Lipid droplets were also present in the cells (not marked in the figure). The gathering of lipid droplets in the cytoplasm of GCs confirmed the presence of these cells in the in vitro primary culture and testified to their metabolic activity. In many of the studies conducted on GCs, it has been suggested that the secretory properties of GCs in primary culture can be used in a coculture with embryos [32]. The research presented here suggests that GCs are capable of proliferation in in vitro culture conditions.

A transcriptomic analysis of proliferating GCs was the main goal of this study. Human GCs undergoing mitotic division showed differentially expressed genes belonging to the "cell cycle arrest", "cell cycle process", "mitotic spindle organization", "mitotic spindle assembly checkpoint", "mitotic spindle assembly", and "mitotic spindle checkpoint" GOs during long-term primary culture conducted in in vitro conditions. The obtained results indicate the key role of these genes during granulosa cell division processes. In our research, special attention was paid to two groups of genes. The first of them included genes belonging to "cell cycle arrest" and "cell cycle process", which are responsible for the regulation of the cell cycle by restricting the progression of the cell cycle during one of its four phases: G1, S, G2, or M. The second class of genes, which contained members of the other four analyzed ontological groups, consisted of genes taking part in the organization and arrangement of the karyokinetic spindle structure during mitosis. During our study, among the members of the gene ontologies of interest, we chose the 10 most upregulated and 10 most downregulated genes. In the course of conducting the analyses, it was found that an increase in gene expression was particularly observed in the "cell cycle arrest" and "cell cycle process" ontology groups. The genes with the most increased expression were FAM64A, ANLN, TOP2A, CTGF, CEP55, BIRC5, PRC1, DLGAP5, GAS6, and NDRG1; while EREG, PID1, INHA, RHOU, CXCL8, SEPT6, EPGN, RDX, WNT5A, and EZH2 were the most downregulated during the time of the culture. While most of the microarray results were validated using RT-qPCR, it needs to be noted that EPGN showed an opposite pattern of expression across all of the culture periods, while INHA exhibited a reversed expression pattern in the first analyzed period of the culture. In these cases, as RT-qPCR is considered to be more quantitatively accurate, the results of the validation were considered in the discussion. The interactions and relations of these genes are presented in Figures 2, 3, and 5. Some of the genes of interest represented more than one ontology groups (Figure 4). All of them belonged to the "cell cycle process" ontology group.

The most upregulated gene was FAM64A (family with sequence similarity 64 member $A$ ), which is also called CATS. During cell division, CATS controls the transition from the metaphase to the anaphase and is considered to be a proliferation marker. A strong expression of CATS is observed in cancer cell lines. Depending on the cell cycle stage, it is induced by mitogens [33]. This gene has been demonstrated to belong to the group of three genes with the highest level in more aggressive triple-negative breast cancer (TNBC) [34]. A high expression of this gene in granulosa cells may reflect a high potential for proliferation and differentiation resembling that occurring in the aggressive forms of breast cancer. The next most upregulated gene was ANLN (anillin actin-binding protein), which encodes an actin-binding protein that is important for growth, migration, and cell cytokinesis [35]. ANLN coordinates and is responsible for the synthesis of several key factors involved in cell division during cytokinesis. Its important roles also involve extracellular adhesion control in mammalian epithelial cells through JNK (c-Jun N-terminal kinase) activity suppression and gap junction regulation [36]. Like with CATS, elevated ANLN expression has been found in many human cancers, including in breast, endometrial, and ovarian cancers [37]. TOP2A (DNA topoisomerase II alpha) controls the state 
of DNA during transcription and plays an essential role in DNA stabilization. The enzyme encoded by this gene coordinates chromosomal condensation processes and chromatid formation and relieves any mechanical strains occurring during transcription and DNA replication. TOP $2 A$ can play an important prognostic role in epithelial ovarian cancer (EOC) [38]. It has also been indicated that TOP2A overexpression occurs in ovarian tumors: it is currently the main target of clinical trials of ovarian cancer therapies [39]. The next analyzed gene was CTGF (connective tissue growth factor), which is often referred to as CCN2. It encodes a protein that is secreted mainly during various pathological tissue conditions, such as increased fibrogenesis and tissue fibrosis. The expression of this gene has been found in several cases of tumors. Members of the connective tissue growth factor (CCN) family regulate cell migration, proliferation, apoptosis, differentiation, and extracellular matrix remodeling. In females, it plays an important role in reproductive organ regulation. Animal models have proven that CTGF is overexpressed in granulosa cells during ovarian follicular development [40]. The current results combined with the results of Cheng et al. [41] confirm the results presented in this study. CEP55 (centrosomal protein 55) is responsible for cytokinesis, and its overexpression is associated with a genetic instability characteristic of breast cancers [42]. The next gene, BIRC5 (baculoviral IAP repeat containing 5), represented the "mitotic spindle assembly" and "cell cycle process" ontology groups. This gene has two basic functions: cell death regulation and mitosis progression control. As in the case of the previously discussed genes, increased BIRC5 overexpression characterizes most types of cancers [43]. The last four most upregulated genes were PRC1 (protein regulator of cytokinesis 1), DLGAP5 (DLG-associated protein 5), GAS6 (growth arrest specific 6), and NDRG1 (N-myc downstream regulated 1). All four genes are overexpressed in various tumors and are considered to be prognostic indicators for several types of cancer. Interestingly, $P R C 1$ is downregulated in Mtor-ZcKO oocytes. Taking the role of PRC1 (protein regulating cytokinesis 1) in the control of somatic cell cytokinesis division into account, a reduced level of its expression in oocytes may indicate that they have reached maturity [44]. From the group of 10 selected downregulated genes, the expression of EREG (epiregulin) decreased the most. Expression of the EREG gene was found in the ovarian GCs as well as in liver progenitor cells. Epiregulin belongs to the EGF (epidermal growth factor) family. It has been proven that its main role is its participation in oocyte maturation, ovulation promotion, and subsequent embryo implantation [45]. A decrease in this gene's expression in the primary in vitro GC culture may have resulted from a lack of bidirectional communication with the oocyte (occurring in physiological conditions). PID1 (phosphotyrosine interaction domain-containing 1) belongs to the family of AKT signaling proteins, additionally mediating antilipolytic insulin action through AKT pathway transduction [46]. The role that it can play in ovarian tissue has not yet been recognized. The next most downregulated gene, representing the "cell cycle process" and "cell cycle arrest" ontology groups, was INHA (inhibin subunit alpha). However, it needs to be noted that its expression was found to be upregulated on day 7 of the primary culture during RT-qPCR validation. Observed mutations in this gene may result in premature ovarian failure in patients. Protein complexes containing INHA negatively regulate the secretion of FSH from the pituitary gland, which may in some way explain the decrease of this gene's expression during the in vitro GC culture. RHOU (ras homolog family member U) mediates the WNT1 signaling pathway, also affecting morphology, proliferation, and cytoskeleton organization [47]. CXCL8 (C-X-C motif chemokine ligand 8) represents the family of inflammatory response mediators. The overexpression of this gene results in poor prognosis in several solid tumors, including epithelial ovarian cancer (EOC). In ovarian cancer, CXCL8 expression induction increases cell viability and proliferation and reduces apoptosis [48]. The last five genes classified in the downregulated group belonged only to the "cell cycle process" ontology group. Among these genes, we could observe very similar levels of expression. This group included the SEPT6 (septin-6), EPGN (epithelial mitogen), RDX (radixin), WNT5A (Wnt family member 5A), and EZH2 (enhancer of zeste 2 polycomb repressive complex 2 subunit) genes. Septins belong to the group of cytoskeleton GTP-binding proteins and take part in cytokinesis during cell division [49]. EPGN stimulated epidermal cell proliferation in the in vitro culture. As a member of the EGF family, it induces cumulus cell expansion in growing ovarian follicles. 
Due to its biochemical properties, EPGN may be an indispensable factor for maintaining cell signaling, and it was also the only gene in this study with an opposite expression pattern detected during RT-qPCR validation [50]. Radixin belongs to the group of cytoskeletal proteins, while Wnt5a affects cell migration processes and tissue angiogenesis. It also has important functions in tissue repair and the maintenance of their permanent state. In healthy ovaries, Wnt5A expression is significantly higher than in those with diagnosed cancer. Wnt5a expression significantly inhibits the proliferation of human EOC cells [51]. EZH2 has oncogenic activity. Its inhibition (EZH2) may disturb cell signaling pathways that lead to tumor cell proliferation, and may simultaneously promote apoptosis in these cells [52].

\section{Conclusions}

The current literature and the results for the genes identified in this study may be used to describe the processes of human ovarian granulosa cells associated with the regulation of cell division and mitotic spindle formation in vitro. The current data showed the differential expression of genes involved in human granulosa cell proliferation processes. GC gene expression was evaluated for up to 30 days of in vitro primary culture. From the six ontological groups (cell cycle arrest (GO: 0007050), cell cycle process (GO: 0022402), mitotic spindle organization (GO: 0007052), mitotic spindle assembly checkpoint (GO: 0007094), mitotic spindle assembly (GO: 0090307), and mitotic spindle checkpoint (GO: 0071174)) we selected and described the 10 most down- and 10 most upregulated genes. Interestingly, most of the analyzed genes were characteristic for the carcinogenesis process. Moreover, the gene overexpression profile in the group of upregulated genes corresponded with the increased expression of these genes in tumor cells. The similar expression profile and ultrastructural imaging between differentiated and divided human GCs in primary culture may indicate their potential to differentiate into cells with cancer-like characteristics. Most of the analyzed genes are used in cancer-related therapeutic approaches. Our results may contribute to the identification of new genes that are helpful in conducting ovarian carcinoma therapies. Moreover, the current findings may indicate new morphological markers for the granulosa cell mitotic division mechanism in growing ovarian follicles. The identification of key genes involved in this process could be explored in subsequent studies. Above all, this study connects a range of currently known cell-cycle-associated genes to in vitro cultured ovarian granulosa cells, bringing further insight into the potential effects of long-term in vitro cultures on the ex vivo behavior of human GCs.

Author Contributions: M.B.: formal analysis, investigation, writing-original draft; W.K.: data curation, investigation, methodology; B.C.: data curation, investigation, methodology; K.K.: methodology, visualization; M.J. (Maurycy Jankowski): investigation, validation; P.C.: formal analysis, software, visualization; M.J. (Michal Jeseta): formal analysis, investigation; H.P.-K.: data curation, validation; L.P.: funding acquisition, resources; M.Z.: funding acquisition, resources; P.M.: data curation, funding acquisition; B.K.: conceptualization, funding acquisition, project administration, supervision, writing-review and editing.

Funding: The publication of this article was made possible by grant number 502-14-02227367-10694 from the Poznan University of Medical Sciences and grant number UMO-2018/31/B/NZ5/02475 from the Polish National Science Center.

Acknowledgments: All of the contributors to this study have been listed as authors of the manuscript.

Conflicts of Interest: The authors declare no conflicts of interest.

\section{References}

1. Chermuła, B.; Brazert, M.; Iżycki, D.; Ciesiółka, S.; Kranc, W.; Celichowski, P.; Ożegowska, K.; Nawrocki, M.J.; Jankowski, M.; Jeseta, M.; et al. New Gene Markers of Angiogenesis and Blood Vessels Development in Porcine Ovarian Granulosa Cells during Short-Term Primary Culture In Vitro. Biomed Res. Int. 2019, 2019, 6545210. [CrossRef]

2. Rybska, M.; Knap, S.; Jankowski, M.; Jeseta, M.; Bukowska, D.; Antosik, P.; Nowicki, M.; Zabel, M.; Kempisty, B.; Jaśkowski, J.M. Characteristic of factors influencing the proper course of folliculogenesis in mammals. Med. J. Cell Biol. 2018, 6, 33-38. [CrossRef] 
3. Rybska, M.; Knap, S.; Jankowski, M.; Jeseta, M.; Bukowska, D. Cytoplasmic and nuclear maturation of oocytes in mammals-living in the shadow of cells developmental capability. Med. J. Cell Biol. 2018, 1. [CrossRef]

4. Kossowska-Tomaszczuk, K.; De Geyter, C. Cells with stem cell characteristics in somatic compartments of the ovary. Biomed Res. Int. 2013, 2013, 310859. [CrossRef] [PubMed]

5. Kossowska-Tomaszczuk, K.; Pelczar, P.; Güven, S.; Kowalski, J.; Volpi, E.; De Geyter, C.; Scherberich, A. A novel three-dimensional culture system allows prolonged culture of functional human granulosa cells and mimics the ovarian environment. Tissue Eng. Part A 2010, 16, 2063-2073. [CrossRef]

6. Kossowska-Tomaszczuk, K.; De Geyter, C.; De Geyter, M.; Martin, I.; Holzgreve, W.; Scherberich, A.; Zhang, H. The Multipotency of Luteinizing Granulosa Cells Collected from Mature Ovarian Follicles. Stem Cells 2009, 27, 210-219. [CrossRef]

7. Moncrieff, L.; Mozdziak, P.; Jeseta, M.; Machatkova, M.; Kranc, W.; Kempisty, B. Ovarian follicular cells-living in the shadow of stemness cellular competence. Med. J. Cell Biol. 2019, 7, 134-140. [CrossRef]

8. Kranc, W.; Brazert, M.; Budna, J.; Celichowski, P.; Bryja, A.; Nawrocki, M.J.; Ożegowska, K.; Jankowski, M.; Chermuła, B.; Dyszkiewicz-Konwińska, M.; et al. Genes responsible for proliferation, differentiation, and junction adhesion are significantly up-regulated in human ovarian granulosa cells during a long-term primary in vitro culture. Histochem. Cell Biol. 2019, 151, 125-143. [CrossRef]

9. Bryja, A.; Dyszkiewicz-Konwińska, M.; Jankowski, M.; Celichowski, P.; Stefańska, K.; Chamier-Gliszczyńska, A.; Popis, M.; Mehr, K.; Bukowska, D.; Antosik, P.; et al. Ion homeostasis and transport are regulated by genes differentially expressed in porcine buccal pouch mucosal cells during long-term culture in vitro-a microarray approach. Bryja al. Med. J. Cell Biol. 2018. [CrossRef]

10. Nawrocki, M.J.; Celichowski, P.; Jankowski, M.; Kranc, W.; Bryja, A.; Borys-Wójcik, S.; Jeseta, M.; Antosik, P.; Bukowska, D.; Bruska, M.; et al. Ontology groups representing angiogenesis and blood vessels development are highly up-regulated during porcine oviductal epithelial cells long-term real-time proliferation-A a primary cell culture approach. Med. J. Cell Biol. 2018, 6, 186-194. [CrossRef]

11. Chermuła, B.; Brazert, M.; Jeseta, M.; Ożegowska, K.; Kocherova, I.; Jankowski, M.; Celichowski, P.; Sujka-Kordowska, P.; Konwerska, A.; Piotrowska-Kempisty, H.; et al. Transcriptomic Pattern of Genes Regulating Protein Response and Status of Mitochondrial Activity Are Related to Oocyte Maturational Competence-A Transcriptomic Study. Int. J. Mol. Sci. 2019, 20, 2238. [CrossRef] [PubMed]

12. Budna, J.; Bryja, A.; Celichowski, P.; Kranc, W.; Ciesiółka, S.; Borys, S.; Rybska, M.; Kolecka-Bednarczyk, A.; Jeseta, M.; Bukowska, D.; et al. "Bone Development" Is an Ontology Group Upregulated in Porcine Oocytes before In Vitro Maturation: A Microarray Approach. DNA Cell Biol. 2017, 36, 638-646. [CrossRef] [PubMed]

13. D'Aurora, M.; Sperduti, S.; Di Emidio, G.; Stuppia, L.; Artini, P.G.; Gatta, V. Inside the granulosa transcriptome. Gynecol. Endocrinol. 2016, 32, 951-956. [CrossRef] [PubMed]

14. Ferraretti, A.P.; La Marca, A.; Fauser, B.C.J.M.; Tarlatzis, B.; Nargund, G.; Gianaroli, L. ESHRE working group on Poor Ovarian Response Definition ESHRE consensus on the definition of "poor response" to ovarian stimulation for in vitro fertilization: The Bologna criteria. Hum. Reprod. 2011, 26, 1616-1624. [CrossRef] [PubMed]

15. Kranc, W.; Budna, J.; Kahan, R.; Chachuła, A.; Bryja, A.; Ciesiółka, S.; Borys, S.; Antosik, M.P.; Bukowska, D.; Brussow, K.P.; et al. Molecular basis of growth, proliferation, and differentiation of mammalian follicular granulosa cells. J. Biol. Regul. Homeost. Agents 2017, 31, 1-8. [PubMed]

16. Kranc, W.; Brązert, M.; Celichowski, P.; Bryja, A.; Nawrocki, M.; Ożegowska, K.; Jankowski, M.; Jeseta, M.; Pawelczyk, L.; Bręborowicz, A.; et al. 'Heart development and morphogenesis' is a novel pathway for human ovarian granulosa cell differentiation during long-term in vitro cultivation-A microarray approach. Mol. Med. Rep. 2019, 19, 1705-1715. [CrossRef]

17. Brazzert, M.; Iżycki, D.; Kranc, W.; Borowiec, B.; Popis, M.; Ożegowska, K.; Bręborowicz, A.; Rachoń, D.; Nowicki, M.; Kempisty, B. Genes involved in hormone metabolism and cellular response in human ovarian granulosa cells. J. Biol. Regul. Homeost. Agents 2019, 33, 461-468.

18. Chomczynski, P.; Sacchi, N. Single-step method of RNA isolation by acid guanidinium thiocyanate-phenol-chloroform extraction. Anal. Biochem. 1987, 162, 156-159. [CrossRef] 
19. Kranc, W.; Brązert, M.; Ożegowska, K.; Nawrocki, M.M.J.; Budna, J.; Celichowski, P.; Dyszkiewicz-Konwińska, M.; Jankowski, M.; Jeseta, M.; Pawelczyk, L.; et al. Expression Profile of Genes Regulating Steroid Biosynthesis and Metabolism in Human Ovarian Granulosa Cells-A Primary Culture Approach. Int. J. Mol. Sci. 2017, 18, 2673. [CrossRef]

20. Budna, J.; Celichowski, P.; Knap, S.; Jankowski, M.; Magas, M.; Nawrocki, M.J.; Ramlau, P.; Nowicki, A.; Rojewska, M.; Chermuła, B.; et al. Fatty Acids Related Genes Expression Undergo Substantial Changes in Porcine Oviductal Epithelial Cells During Long-Term Primary Culture. Med. J. Cell Biol. 2018, 6, 39-47. [CrossRef]

21. Kranc, W.; Brązert, M.; Ożegowska, K.; Budna-Tukan, J.; Celichowski, P.; Jankowski, M.; Bryja, A.; Nawrocki, M.J.; Popis, M.; Jeseta, M.; et al. Response to abiotic and organic substances stimulation belongs to ontologic groups significantly up-regulated in porcine immature oocytes. Med. J. Cell Biol. 2018, 6, 91-100. [CrossRef]

22. Stefańska, K.; Chamier-Gliszczyńska, A.; Jankowski, M.; Celichowski, P.; Kulus, M.; Rojewska, M.; Antosik, P.; Bukowska, D.; Bruska, M.; Nowicki, M.; et al. Epithelium morphogenesis and oviduct development are regulated by significant increase of expression of genes after long-term in vitro primary culture-A microarray assays. Med. J. Cell Biol. 2018, 6, 195-204. [CrossRef]

23. Stefańska, K.; Kocherova, I.; Knap, S.; Kulus, M.; Celichowski, P.; Jeseta, M. The genes regulating maintenance of cellular protein location are differentially expressed in porcine epithelial oviductal cells during longterm in vitro cultivation. Med. J. Cell Biol. 2019, 7, 77-85. [CrossRef]

24. Huang, D.W.; Sherman, B.T.; Tan, Q.; Kir, J.; Liu, D.; Bryant, D.; Guo, Y.; Stephens, R.; Baseler, M.W.; Lane, H.C.; et al. DAVID Bioinformatics Resources: Expanded annotation database and novel algorithms to better extract biology from large gene lists. Nucleic Acids Res. 2007, 35, W169-W175. [CrossRef]

25. Von Mering, C.; Jensen, L.J.; Snel, B.; Hooper, S.D.; Krupp, M.; Foglierini, M.; Jouffre, N.; Huynen, M.A.; Bork, P. STRING: Known and predicted protein-protein associations, integrated and transferred across organisms. Nucleic Acids Res. 2004, 33, D433-D437. [CrossRef]

26. Walter, W.; Sánchez-Cabo, F.; Ricote, M. GOplot: An R package for visually combining expression data with functional analysis. Bioinformatics 2015, 31, 2912-2914. [CrossRef]

27. Chamier-Gliszczyńska, A.; Brazert, M.; Sujka-Kordowska, P.; Popis, M.; Ożegowska, K.; Stefańska, K.; Kocherova, I.; Celichowski, P.; Kulus, M.; Bukowska, D.; et al. Genes involved in angiogenesis and circulatory system development are differentially expressed in porcine epithelial oviductal cells during long-term primary in vitro culture-A transcriptomic study. Med. J. Cell Biol. 2018, 6, 163-173. [CrossRef]

28. Kocherova, I.; Kulus, M.; Dompe, C.; Antosik, P.; Bukowska, D. Biochemical properties of cofactor and coenzyme metabolism in porcine oviductal epithelial cells -A microarray study. 2019. [CrossRef]

29. Morey, J.S.; Ryan, J.C.; Van Dolah, F.M. Microarray validation: Factors influencing correlation between oligonucleotide microarrays and real-time PCR. Biol. Proced. Online 2006, 8, 175-193. [CrossRef]

30. Thompson, W.E.; Branch, A.; Whittaker, J.A.; Lyn, D.; Zilberstein, M.; Mayo, K.E.; Thomas, K. Characterization of Prohibitin in a Newly Established Rat Ovarian Granulosa Cell Line. Endocrinology 2001, 142, 4076-4085. [CrossRef]

31. Rotmensch, S.; Dor, J.; Furman, A.; Rudak, M.E.; Mashiach, S.; Amsterdam, A. Ultrastructural characterization of human granulosa cells in stimulated cycles: Correlation with oocyte fertilizability. Fertil. Steril. 1986, 45, 671-679. [CrossRef]

32. Nottola, S.A.; Heyn, R.; Camboni, A.; Correr, S.; Macchiarelli, G. Ultrastructural characteristics of human granulosa cells in a coculture system for in vitro fertilization. Microsc. Res. Tech. 2006, 69, 508-516. [CrossRef] [PubMed]

33. Archangelo, L.F.; Greif, P.A.; Maucuer, A.; Manceau, V.; Koneru, N.; Bigarella, C.L.; Niemann, F.; dos Santos, M.T.; Kobarg, J.; Bohlander, S.K.; et al. The CATS (FAM64A) protein is a substrate of the Kinase Interacting Stathmin (KIS). Biochim. Biophys. Acta Mol. Cell Res. 2013, 1833, 1269-1279. [CrossRef] [PubMed]

34. Zhang, C.; Han, Y.; Huang, H.; Min, L.; Qu, L.; Shou, C. Integrated analysis of expression profiling data identifies three genes in correlation with poor prognosis of triple-negative breast cancer. Int. J. Oncol. 2014, 44, 2025-2033. [CrossRef]

35. Piekny, A.J.; Maddox, A.S. The myriad roles of Anillin during cytokinesis. Semin. Cell Dev. Biol. 2010, 21, 881-891. [CrossRef] 
36. Wang, D.; Chadha, G.K.; Feygin, A.; Ivanov, A.I. F-actin binding protein, anillin, regulates integrity of intercellular junctions in human epithelial cells. Cell. Mol. Life Sci. 2015, 72, 3185-3200. [CrossRef]

37. Hall, P.A.; Todd, C.B.; Hyland, P.L.; McDade, S.S.; Grabsch, H.; Dattani, M.; Hillan, K.J.; Russell, S.E.H. The septin-binding protein anillin is overexpressed in diverse human tumors. Clin. Cancer Res. 2005, 11, 6780-6786. [CrossRef]

38. Ghisoni, E.; Maggiorotto, F.; Borella, F.; Mittica, G.; Genta, S.; Giannone, G.; Katsaros, D.; Sciarrillo, A.; Ferrero, A.; Sarotto, I.; et al. TOP2A as marker of response to pegylated lyposomal doxorubicin (PLD) in epithelial ovarian cancers. J. Ovarian Res. 2019, 12, 17. [CrossRef]

39. Miles, G.D.; Seiler, M.; Rodriguez, L.; Rajagopal, G.; Bhanot, G. Identifying microRNA/mRNA dysregulations in ovarian cancer. BMC Res. Notes 2012, 5, 164. [CrossRef]

40. Wandji, S.A.; Gadsby, J.E.; Barber, J.A.; Hammond, J.M. Messenger ribonucleic acids for MAC25 and connective tissue growth factor (CTGF) are inversely regulated during folliculogenesis and early luteogenesis. Endocrinology 2000, 141, 2648-2657. [CrossRef]

41. Cheng, J.-C.; Chang, H.-M.; Fang, L.; Sun, Y.-P.; Leung, P.C.K. TGF- $\beta 1$ Up-Regulates Connective Tissue Growth Factor Expression in Human Granulosa Cells through Smad and ERK1/2 Signaling Pathways. PLoS ONE 2015, 10, e0126532. [CrossRef] [PubMed]

42. Kalimutho, M.; Sinha, D.; Jeffery, J.; Nones, K.; Srihari, S.; Fernando, W.C.; Duijf, P.H.; Vennin, C.; Raninga, P.; Nanayakkara, D.; et al. CEP55 is a determinant of cell fate during perturbed mitosis in breast cancer. EMBO Mol. Med. 2018, 10, e8566. [CrossRef] [PubMed]

43. Brodská, B.; Otevřelová, P.; Holoubek, A. Decitabine and SAHA-induced apoptosis is accompanied by survivin downregulation and potentiated by ATRA in p53-deficient cells. Oxid. Med. Cell. Longev. 2014, 2014, 165303. [CrossRef] [PubMed]

44. Guo, J.; Zhang, T.; Guo, Y.; Sun, T.; Li, H.; Zhang, X.; Yin, H.; Cao, G.; Yin, Y.; Wang, H.; et al. Oocyte stage-specific effects of MTOR determine granulosa cell fate and oocyte quality in mice. Proc. Natl. Acad. Sci. USA. 2018, 115, E5326-E5333. [CrossRef] [PubMed]

45. Zheng, Q.; Zhou, F.; Cui, X.; Liu, M.; Li, Y.; Liu, S.; Tan, J.; Yan, Q. Novel Serum Biomarkers Detected by Protein Array in Polycystic Ovary Syndrome with Low Progesterone Level. Cell. Physiol. Biochem. 2018, 46, 2297-2310. [CrossRef]

46. Yin, C.; Liu, W.; hua; Liu, Y.; Wang, L.; Xiao, Y. PID1 alters the antilipolytic action of insulin and increases lipolysis via inhibition of AKT/PKA pathway activation. PLoS ONE 2019, 14, e0214606. [CrossRef]

47. Kong, D.; Guan, Q.; Li, G.; Xin, W.; Qi, X.; Guo, Y.; Zhao, J.; Xu, J.; Sun, S.; Gao, L. Expression of FSHR in chondrocytes and the effect of FSH on chondrocytes. Biochem. Biophys. Res. Commun. 2018, 495, 587-593. [CrossRef]

48. Gatla, H.R.; Zou, Y.; Uddin, M.M.; Singha, B.; Bu, P.; Vancura, A.; Vancurova, I. Histone Deacetylase (HDAC) Inhibition Induces IкB Kinase (IKK)-dependent Interleukin-8/CXCL8 Expression in Ovarian Cancer Cells. J. Biol. Chem. 2017, 292, 5043-5054. [CrossRef]

49. O'Neill, R.S.; Clark, D.V. Partial Functional Diversification of Drosophila melanogaster Septin Genes Sep2 and Sep5. G3 (Bethesda) 2016, 6, 1947-1957. [CrossRef]

50. Carletti, M.Z.; Christenson, L.K. Rapid effects of LH on gene expression in the mural granulosa cells of mouse periovulatory follicles. Reproduction 2009, 137, 843-855. [CrossRef]

51. Jin, P.; Song, Y.; Yu, G. The Role of Abnormal Methylation of Wnt5a Gene Promoter Regions in Human Epithelial Ovarian Cancer: A Clinical and Experimental Study. Anal. Cell. Pathol. 2018, 2018, 1-9. [CrossRef] [PubMed]

52. Lu, B.; Shi, H. An In-Depth Look at Small Cell Carcinoma of the Ovary, Hypercalcemic Type (SCCOHT): Clinical Implications from Recent Molecular Findings. J. Cancer 2019, 10, 223-237. [CrossRef] [PubMed]

(C) 2019 by the authors. Licensee MDPI, Basel, Switzerland. This article is an open access article distributed under the terms and conditions of the Creative Commons Attribution (CC BY) license (http://creativecommons.org/licenses/by/4.0/). 